This work is licensed under a Creative Commons Attribution 4.0 International License.

Ovaj rad dostupan je za upotrebu pod međunarodnom licencom Creative Commons Attribution 4.0.

Filip Galović

\title{
FONOLOŠKI SUSTAV PRAŽNIČKOGA GOVORA
}

dr. sc. Filip Galović, Hrvatsko katoličko sveučilište, filip.galovic@unicath.hr, Zagreb

izvorni znanstveni članak

UDK 811.163.42'282(497.5)(210.7 Brač)

rukopis primljen: 26. 9. 2017.; prihvaćen za tisak: 16. 11. 2017.

Premda se premoćan broj značajki mjesnoga govora Pražnica na otoku Braču može iščitati iz prošlostoljetnih sintetskih opisa bračkih čakavskih idioma, ovaj govor do sada nije samostalno opisan ni na jednoj jezičnoj ravni, a o njemu postoje tek poneki parcijalni podatci. U članku se na temelju recentnih terenskih istraživanja prikazuju fonološke posebnosti pražničkoga govora. Analizom se pokazalo da je mjesni govor Pražnica čvrst sustav koji je sačuvao svoju strukturu i da novije promjene i inovacije, koje su dotaknule pojedine bračke idiome, nisu zadrle u ovaj govor.

Ključne riječi: čakavsko narječje; južnočakavski dijalekt; brački govori; govor Pražnica; fonologija

\section{Uvod}

Naselje Pražnica, koje se spominje još u Povaljskoj listini (Šimunović 2005: 199), smješteno je u središnjem dijelu otoka Brača oko 7 kilometara južnije od Pučišća, čijoj općini i pripada. Prema podatcima Državnoga zavoda za statistiku iz 2011. godine u Pražnicama živi 371 duša. Mnogi su stanovnici i danas težaci, bave se stočarstvom i poljodjelstvom. Ondje se nalazi dječji vrtić, osnovna škola (četiri razreda), pošta, prodavaonica i gostionica. Župna je crkva sv. Ante Opata sagrađena 1400. godine, koji je glavni patron župe i koji se slavi na poseban način. Pražničani mnogo drže do crkvenih i pučkih pobožnosti pa se osobito štuje Veliki tjedan, Tijelovo, Velika Gospa, Svi Sveti i Božić.

Govor je naselja Pražnica čakavski. Iako brojni čimbenici danas mijenjaju strukturu nekih govora, izgledno je da je pražnički idiom čvrst sustav koji se 
uvelike opire mijenama i da su mogući nanosi sasvim ograničena domašaja. Govor je ovoga naselja dobro sačuvan u sviju naraštaja, a potrebito je naglasiti da domaćim idiomom beziznimno govori i najmlađi svijet.

\section{Brački govori i pražnički govor u dosadanjoj dijalektološkoj literaturi}

Vrijedan je opis jezičnih posebnosti bračkih čakavskih govora objavio Mate Hraste početkom 40-ih godina (Čakavski dijalekat ostrva Brača), a slične opise 70-ih godina objavljuje Petar Šimunović (Čakavština srednjodalmatinskih otoka; Ogled jezičnih osobina bračke čakavštine). Govor je Pražnica, pored govora Ložišća i Sumartina, istražen u drugoj polovici XX. stoljeća kao punkt za Hrvatski jezični atlas. Ispunjeni se kvestionari čuvaju u Institutu za hrvatski jezik i jezikoslovlje u Zagrebu, a tadanja istraživanja govora spomenutih bračkih idioma, nažalost, do dan-danas nisu objavljena. ${ }^{1}$ Pražnički je govor 80-ih godina obuhvaćen u istraživanju sličnosti i razlika govora otoka Brača (Sličnosti i razlike u govorima otoka Brača kao odraz migracijskih kretanja), odnosno terenski je ispitano 350 riječi bazičnoga rječnika svakoga od 16 bračkih naselja (Sujoldžić, Finka, Šimunović, Rudan). Petar Šimunović početkom je ovoga stoljeća objavio opsežan Rječnik bračkih čakavskih govora, kojemu je temelj govor rodne mu Dračevice. U novije se vrijeme nekim bračkim idiomima bavi Filip Galović koji je objavio nekoliko članaka o njima. Nataša Šprljan na temelju je duljega terenskoga rada godine 2015. doktorirala na akcentuaciji govora Selaca.

Govor Pražnica do sada nije samostalno opisan ni na jednoj jezičnoj ravni. Tek se pojedine dijalektološke pripomene o ovome govoru mogu pronaći, primjerice, u pjesničkoj zbirci pisanoj pražničkim govorom Pod zvizdamin ili U pustinji jubavi Tomislava Dorotića, a koje je ispisao Petar Šimunović. Spomenuti je Tomislav Dorotić pisao poeziju hrvatskim standardnim jezikom, ali i čakavskim govorom Pražnica, a u novije vrijeme i mlada Silvija Buvinić piše zanimljive stihove ovim mjesnim govorom, pa i oni stanovitim dijelom mogu upotpuniti poneka saznanja o pražničkome idiomu. Valja ovdje navesti i Prožniški libar. Riči, judi, zgode i još puno tega, sve prožniško Ive Ivelića iz 2015. godine koji je potonju knjigu napisao bez znanstvenih

1 Iako je za nove analize poželjno proučavanje i starije građe, ispunjeni mi kvestionar nije bio dostupan, stoga ranije zabilježeni podatci nisu bili uvršteni u ovaj rad. Rad se u cijelosti oslanja na nova terenska istraživanja autora ovoga rada. 
pretenzija, iz ljubavi prema svojemu naselju i ljudima ondje. Godine 2017. Josip Lisac objavljuje rad Pražnički govor u poeziji Tomislava Dorotića u kojem raščlanjuje jezik Dorotićeve zbirke Pod zvizdamin. U pripremi je za tisak članak Zdravke Biočine, Ive Bašić i Gordane Varošanec-Škarić koji se bavi prozodijskim sustavom pražničkoga govora s akustičke strane.

\section{Recentno terensko istraživanje pražničkoga govora}

Ciljem je recentnoga terenskoga istraživanja bilo zabilježiti i analizirati fonološke posebnosti pražničkoga idioma. Istraživanja su na terenu intenzivno vršena u kolovozu 2017. godine. Mnoge su karakteristike govora ovjerene u slobodnim razgovorima s konzultantima, a vrijedan je materijal dobiven pomoću posebno koncipiranoga kvestionara na temelju su kojega ispitane pojedine značajke govora na fonološkoj ravni.

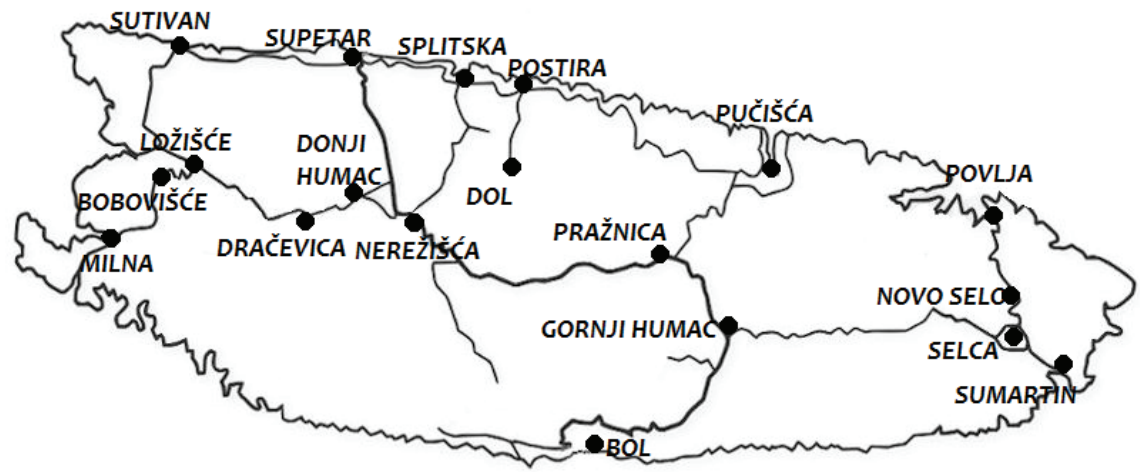

Karta 1. Geografski položaj područja istraživanja

Glavnim su informatorima bili Marija Kusanović (rođ. Klinčić) (1930.) i Silvija Buvinić (1993.). Pojedini su važni podatci dobiveni od Franke Jerčić (1926.), Frane Jerčića (1928.), don Tonča Kusanovića (1951.) i Slobodana Kusanovića (1957.). Iako je nakon djetinjstva živjela van Pražnica, a danas u Zagrebu, pražnički je govor dobro konzervirala Rosanda Dorotić (rođ. Kojatić) (1928.) koja je ispričala mnoge pražničke zgode i odgovorila na brojna pitanja. ${ }^{2}$ Ista mi je predala podeblji rukopis s pražničkim riječima

2 Riječ je, upravo, o supruzi spomenutoga Tomislava Dorotića koji je njezinim idiomom pisao poeziju znatne književne vrijednosti, ali veoma vrijedne i s dijalektološkog aspekta. 
koje je prikupljao njezin suprug, pa su poneke riječi iz toga korpusa također bile provjerene kod izvornih govornika i uvrštene u ovaj rad. Neke sam podatke uspio čuti i zapisati od starije muške čeljadi koja se nedjeljom okuplja „pol murvon” u središtu naselja.

\section{Fonologija mjesnoga govora Pražnica na otoku Braču}

\subsection{Vokalski sustav}

4.1.1. Vokalski se sustav mjesnoga govora Pražnica sastoji od ovih jedinica:

$\bar{\imath}$

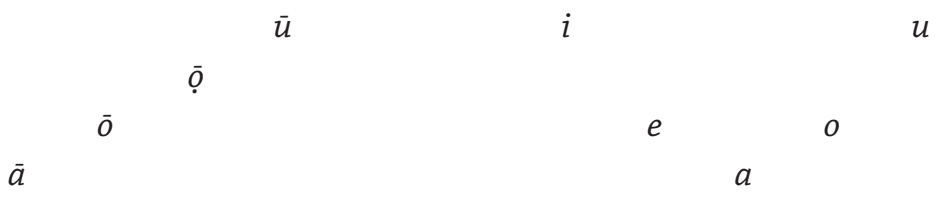

Funkciju silabema vrši i r.

4.1.2. Vokal koji prethodi dočetnomu nazalu okaziono može preuzeti nazalnost: [jedô] ('jedan'), [jūdìmq̨] DLI mn.

Na mjestu se nekadanje duljine može javiti blaga zatvorenost kratkoga zanaglasnoga $o$.

4.1.3. Distribucija je vokalskih fonema pretežito slobodna. Svaki od vokala, u načelu, može stajati u inicijalnoj, medijalnoj i finalnoj poziciji u riječi, ispred i iza bilo kojega konsonanta, osim uz r.

Dugi vokali, osim $\bar{a}$, mogu stajati pod dugim akcentom i u dugome nenaglašenome slogu, koji se, sudeći po prikupljenome materijalu, može ostvariti neposredno ispred kratkoga silaznoga ili dugoga silaznoga akcenta. Vokal à u pravilu se javlja samo u naglašenim nefinalnim slogovima i pod akutom. ${ }^{3}$ Dakle, takav $\bar{a}$ ne mijenja vokalsku boju za razliku od polaznog $\bar{a}$ koji se zatvorio do $\bar{o}$, a čija se zatvorenost čuva i u naknadno pokraćenim zanaglasnim slogovima.

Kratki vokali mogu stajati pod akcentom te ispred i iza akcenta.

3 Usamljeni su primjeri u kojima a dolazi pod dugim silaznim akcentom, npr. gâšo ('lijenčina'), kâpo ('upravitelj stoja'), Grâmpa (nadimak) ili u nenaglašenim slogovima, npr. konzulātä G jd. 
Slogotvorni je $r$ uvijek kratak, ${ }^{4}$ a može biti naglašen i nenaglašen. U načelu se pojavljuje između dvaju nevokala. Za ovoga istraživanja nema potvrde da fonem $r$ vrši slogotvornu funkciju u inicijalnome položaju ispred konsonanta. U govoru se čuje prilog stopr̃ ('ovaj čas, upravo'), gdje je r postavljen na samome koncu riječi, ali i ondje pred $r$ može prirasti popratni $e$.

Tablica 1. Primjeri dugih naglašenih i nenaglašenih vokala

\begin{tabular}{|c|c|c|c|}
\hline \multirow{2}{*}{ vokal } & \multirow{2}{*}{ naglašen } & \multicolumn{2}{|l|}{ nenaglašen } \\
\hline & & prednaglasni & zanaglasni \\
\hline a & $\begin{array}{l}\text { lozãmi(n) DLI mn., pijãca, } \\
\text { drãča }\end{array}$ & - & - \\
\hline ẹ & $\begin{array}{l}\text { divotẹ G jd., kotlệnka, protrệsli } \\
\text { gl. pridj. rad. m. mn. }\end{array}$ & $\begin{array}{l}\text { krẹcùla gl. pridj. rad. ž. jd. } \\
\text { ('rukom otkidati grane'), } \\
\text { poštèrèrà GA jd. ('poštar'), } \\
\text { uštẹedi gl. pridj. rad. m. jd. }\end{array}$ & - \\
\hline i & $\begin{array}{l}\text { duzîna ('dvanaest jednakih } \\
\text { predmeta'), lǐšte, razumîn }\end{array}$ & $\begin{array}{l}\text { dobrīčăa ('dobro čeljade'), jìtệ, } \\
\text { mučiteè 2. mn. prez. }\end{array}$ & - \\
\hline $\mathbf{o}$ & $\begin{array}{l}\text { baraškôda ('tuča, skandal'), } \\
\text { četvrtõk ('konj od četiri } \\
\text { godine'), nadõren neodr. pridj. } \\
\text { m. jd. }\end{array}$ & $\begin{array}{l}\text { gńōvìt, izōjdìte 2. mn. imp!, } \\
\text { odōvàt ('udavati') }\end{array}$ & - \\
\hline o & $\begin{array}{l}\text { dọ̃jdemo 1. mn. prez., prodộl, } \\
\text { svojộn DL jd. }\end{array}$ & $\begin{array}{l}\text { dvộrìma(n) DLI mn., Gọ̄spà, } \\
\text { mộrù DL jd. }\end{array}$ & - \\
\hline $\mathbf{u}$ & $\begin{array}{l}\text { krakũn ('zasun'), lũžńok } \\
\text { ('komad krpe u procesu } \\
\text { lušijavanja'), polprûg ('dio } \\
\text { samara') }\end{array}$ & $\begin{array}{l}\text { xūpìt ('prijati'), jūbôv, tūstà } \\
\text { neodr. pridj. ž. jd. }\end{array}$ & - \\
\hline
\end{tabular}

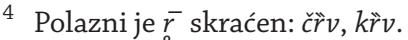


Tablica 2. Primjeri kratkih naglašenih i nenaglašenih vokala

\begin{tabular}{|c|c|c|c|}
\hline \multirow{2}{*}{ vokal } & \multirow{2}{*}{ naglašen } & \multicolumn{2}{|c|}{ nenaglašen } \\
\hline & & prednaglasni & zanaglasni \\
\hline a & $\begin{array}{l}\text { ispovidä̀t, xudobà, } \\
\text { ramenä } \mathrm{N} \text { mn. }\end{array}$ & $\begin{array}{l}\text { banïca ('stari } \\
\text { austrougarski kovani } \\
\text { novčić), kalamita } \\
\text { ('gromobran'), vazmì } \\
\text { 2. jd. imp! }\end{array}$ & $\begin{array}{l}\text { ingvãštar ('katran'), } \\
\text { krüxa G jd., mrïža }\end{array}$ \\
\hline e & $\begin{array}{l}\text { jêmomo 1. mn. prez., } \\
\text { potrëfilo gl. pridj. rad. s. } \\
\text { jd., zovê 3. jd. prez. }\end{array}$ & $\begin{array}{l}\text { glavešina, jemãtva } \\
\text { ('berba grožđa'), } \\
\text { serenôda }\end{array}$ & $\begin{array}{l}\text { köstret, xãješ 2. jd. prez. } \\
\text { ('mariti'), mìsečini DL } \\
\text { jd. }\end{array}$ \\
\hline i & $\begin{array}{l}\text { mìslila gl. pridj. rad. ž. } \\
\text { jd., pokažìvoli gl. pridj. } \\
\text { rad. m. mn., ježuvìt } \\
\text { ('isusovac') }\end{array}$ & $\begin{array}{l}\text { decimõr ('decimalna } \\
\text { vaga'), fabricệr ('član } \\
\text { crkvenoga savjeta'), } \\
\text { škurinẹ G jd. }\end{array}$ & $\begin{array}{l}\text { čimãvica, gãzit, } \\
\text { govôrimo 1. mn. prez. }\end{array}$ \\
\hline o & $\begin{array}{l}\text { börima(n) DLI mn., } \\
\text { būzdö ('glupan'), doxôdi } \\
\text { 3. jd. prez. }\end{array}$ & godište, grdobà, svidočìt & $\begin{array}{l}\text { cĩpomo 1. mn. prez., } \\
\text { gütov neodr. pridj. m. } \\
\text { jd. ('neokretan'), ìspovid }\end{array}$ \\
\hline $\mathbf{u}$ & $\begin{array}{l}\text { kadüja, ümisto pril., } \\
\text { živedü } 3 . \text { mn. prez. }\end{array}$ & $\begin{array}{l}\text { faturềta, fortunõl ('jak } \\
\text { vjetar, oluja'), prutït' }\end{array}$ & $\begin{array}{l}\text { barìlu DL jd., jãbuka, } \\
\text { parcëlu A jd. }\end{array}$ \\
\hline
\end{tabular}

Tablica 3. Silabem r

\begin{tabular}{|c|c|c|c|}
\hline \multirow{2}{*}{ kratak } & \multirow{2}{*}{ naglašen } & \multicolumn{2}{|c|}{ nenaglašen } \\
\hline & & prednaglasni & zanaglasni \\
\hline 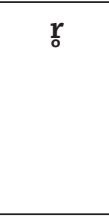 & $\begin{array}{l}\text { kr̀t ('komad'), navr̈tot } \\
\text { ('navrtati'), nōpristak } \\
\text { ('naprstak') }\end{array}$ & $\begin{array}{l}\text { xržĩ 3. jd. prez., vrvïca } \\
\text { ('konop od kozje } \\
\text { dlake'), zafrkōvät }\end{array}$ & $\begin{array}{l}\text { nëkrst ('nekršteno } \\
\text { čeljade, nevjernik'), } \\
\text { nïzbrdo pril., tãprč } \\
\text { ('ostatak posječenoga } \\
\text { stabla') }\end{array}$ \\
\hline
\end{tabular}

4.1.4. Dvočlane su vokalske sekvencije obične: àuti N mn., kaìt', kaïš, kalaìsor, lêut, mjaũče 3. jd. prez., naučìt, naüšan, praunük, priurệdït, rệuma, zainōdìt se ('zainatiti se'), zaüjit ('začiniti uljem') iako je u pojedinim primjerima registrirano razbijanje zijeva umetanjem sonanta $j$ ili v: gostijọna, kamijộnì N mn., tejộtar; bavũl, ježuvìt ('isusovac'). Zijev može biti spriječen kontrakcijom: kôda ('kao da'), nôpoko, pôs ('pojas'), stõt ('stajati; boraviti). Zabilježen je oblik vâ ('valja'), pored nekontrahiranoga, a dolaze i primjeri poput nĩmomo ('nemamo'). 
4.1.5. Finalni je vokal $i$ dosljedno reduciran u dočetku glagolskoga priloga sadašnjega (pìvojut') te u infinitivnome dočetku (pomöt’, skrōtìt), a fakultativno je isključenju sklon i finalni $-t$ (prodōvä). ${ }^{5}$ Redukcije su vokala zamijećene u oblicima imperativa (mǔč, müšte). Vokal može otpasti u pojavnicama tipa onãmo/nãmo, ${ }^{6}$ nüda/onüda i sl.

4.1.6. Dodavanje je vokala evidentirano u primjeru $s$ mènon gdje se vokal $e$ analoški umeće. Sustavno se govori omệndula ('badem'), ômira ('mjera'), orệbàc ('vrabac'), dakle s predmetanjem vokala $o$. Fakultativno je dodavanje vokala registrirano u primjerima tipa otî/tî, otộ/tộ.

Prijedlozima, koji svršavaju na konsonant, u poziciji proklize ispred drugoga konsonanta ponekad može prionuti vokal: uza nîdra, niza skãle.

$\mathrm{U}$ dijelu su ovjera strane konsonantske skupine u finalnoj poziciji uklonjene uvrštenjem vokala između sastavnica konsonatske skupine: fundamềnat, inkãnat ('dražba, ovrha'), tastamềnat ('oporuka'). Čuo sam u Pražnicama i asvãlat ('asfalt').

4.1.7. U izoliranim riječima uz inicijalni vokal može biti postavljen konsonant $j \mathrm{u}$ protetskoj službi. Redovito se govori jũsta, nerijetko i

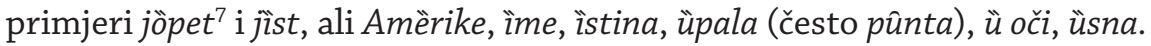

4.1.8. Čakavski su govori otoka Brača dijelom južnočakavskoga dijalekta, stoga je riječ o ikavskim govorima. U pražničkome je idiomu 'jat' sustavno zamijenjen vokalom $i$ u korijenskim, tvorbenim i gramatičkim morfemima: cvît, dvî, kolìno, kudîja, mišìna ('mješina'), ovĩx, poletìt, smĩx, svidök, u sëbi, vrîdan neodr. pridj. m. jd., zabīìt.

Brački čakavski idiomi sadrže i ograničen broj stalnih ekavizama, ${ }^{8}$ koji su zasvjedočeni i u mjesnome govoru Pražnica: cêsta, kôren, ${ }^{9}$ öbedvî, ozlẹdìt, starešina, telesìna, zanovẹttàt, osệknüt (se) i još neki. Noviji je ekavizam na

\footnotetext{
5 Nema redukcije finalnoga - $t$ u primjerima tipa vazẹst.

6 Tu se čuje i akcent onāmö/onãmo, nāmö/nãmo; ovāmö/ovãmo, vāmö/vãmo i sl.

7 Možda od $i+$ opet.

8 Hraste navodi: „Zamenu ovoga glasa [ě] sa e nalazimo u istim rečima kao i na Hvaru, dakle: vềnac, ozlēdì $(t)$, òzleda, staresìna i starišìna, ôseka, osēknü $(t)$, zềnica i zìnica, vềja $i$ vìja, sêst, sedî( $(t)$ i sidì( $(t)$, sedĩn $i$ sidĩn. Ovamo bi se mogle ubrojiti i reči: zanovētà $(t)$, kören, korẽnje, iskorēnï(t), gồre, dôle i gồri, dôli...” (1940: 17). Slično ističe i Šimunović: „U njima [bračkim govorima] se ipak nalazi nekoliko ekavizama kao npr. u leksemima: vênac, òzleda, kören, telesồ, starešina, osẹknuìt, ozlẹdìt, zanovẹtầt (...), vretenồ, ôbe, ôbedvi, Bëlić, kôstret, jãstreb, sest, u kojem je e vjerojatno ujednačen prema prezentu (*sędQ)" (2009: 23).

9 Tu nije sigurno potječe li $e$ od 'jata' ili staroga $e$.
} 
prīmệr. Mnogi čakavski govori otoka Brača poznaju ekavizam zềnica, no za ovoga je istraživanja u pražničkome notirano zìnica. Ovjeren je lik sêst, koji je nastao analogijom prema praslavenskomu prezentskomu obliku *sędo, pa odatle i obilati primjeri: prisêst, sêst - sêla - sệ, zasêst.

Govore se oblici tộte/tộtê, ovộde/ovộề u kojima u rjeđim okolnostima može zamuknuti krajnji vokal pa se čuje tột, ovộd, gôr i sl.

Supstitucija se 'jata' vokalom $i$ zrcali i u leksemima tipa gńizzdô, nîdra, orìx. Prijedlog 'prema' glasi prìma, a vokal i stoji i u složenici primalîte.

U riječi je romanskoga postanja prãska ('breskva') evidentirana stara mijena ${ }^{*} \check{e}>a$.

Posvema je prirodno da se okaziono javlja i jekavski odraz, pretežito u pokojoj riječi iz novijega nanosa, no ta pojava nimalo ne ugrožava ikavski tip govora: cjệv, mjêrilo, Nẹemàc, osjẹeton 1 . jd. prez.

4.1.9. Kontinuata je starohrvatskoga 'šva' $\left(a<{ }^{*} b,{ }^{*} b\right)$ sustavno vokal $a$, odnosno nakon kasnije kvalitativne promjene i o: dôn, lagàt, ògoń, otâc, pàs, rôž, smökov G mn., sôn, tîsan, vìtar.

U čitavoj se paradigmi imenice 'pas' proteže vokal a: pasà GA jd.- pasù DL jd. - pasộn I jd. - pasî̀ N mn. itd.

Čakavskim su govorima, uz pokoju ovjeru u štokavskim i kajkavskim govorima, svojstveni primjeri nepreventivnih punih vokalizacija slaboga 'šva', što je registrirano i u govoru Pražnica: jaglà, vãzda, vazệst - vazệla vazmì. ${ }^{10} \mathrm{U}$ oblicima se glagola 'uzeti' ipak danas sukobljavaju likovi va- i u-. Govori se Uzmä (pored novijega Uskřss), a i u ostalim je nalazima potvrđeno u-: udovìca, unük, ušênak, ùvik, užgàt, uz usamljeni slučaj tộrij ('utorak') gdje je inicijalno $v$ u ishodišnojezičnome prefiksu ${ }^{*} v b^{-}>v \partial-$ nakon likvidacije poluglasa otpalo. Dakako, dolaze primjeri kao u brodû, u têbi, u selü, koji prezentiraju da je protojezični prijedlog ${ }^{*} v ъ>v ə$ sustavno prešao u $u$.

4.1.10. Protojezični i starojezični fonem *l konsekventno je reflektirao u vokal u: dūbăt, dužinà, jãbuka, pomüst, požūtìt, pûn, sûnce, suzâ, tûst, vüna.

Protojezični stražnji nazal ${ }^{*}$, odnosno starojezični $o$, dobio je supstituciju $u$, čime je podudaran s refleksom *l: büdeš 2. jd. prez., dûb, grûb, izmūtìt, klûko ('klupko'), kupìnica, kûs, mojü A jd., mūkä ('brašno'), mûž, pầuk, prût, pũt, utrôbica, žejûd.

10 Pojavi se jake čakavske vokalnosti mogu pridodati i zatvoreni vokali (Moguš 1977: 2329). 
4.1.11. Rezultat je denazalizacije protojezičnoga prednjega nazala ${ }^{*} \ell \mathrm{u}$ čakavskome narječju dvojak. U ispitivanome je idiomu starija zamjena vokalom a u nekadanjoj poziciji ${ }^{*} e$ nakon palatala $j, \check{c}$, $\check{z}$ provedena u primjerima: jazïk, požăt, žãnot, zajõt - zajõla, ujõt - ujõla - ujõtemo te nešto rjeđe prijõt. Stariji je svijet govorio žãtva, no taj se leksem danas u govoru zadržao samo kao trag. U navedenoj je poziciji uočena i novija zamjena: jêčam, načêet - nãčeli, počệt - počệla, žẽdan, žẽja ('žeđa'). ${ }^{11}$ Razumije se, u slijedu je nepalatalnoga konsonanta nosnik ${ }^{*} e$ jednoznačno zamijenjen vokalom e: brìme, desẹtäk, mệso, napẹ̃t inf., pãmet, telëtina.

4.1.12. Slogotvorni je $r$ uvijek kratak i nema popratnoga vokala, a može biti naglašen ili nenaglašen: břž ('možda'), navřte 3. jd. prez. ('kalemiti, navrtati'), přrč, sř̀ce, zavr̂̀nen 1. jd. prez.; držãva, krmẽj, prvî, ukrcât; nìzbrdo, üzbrdo.

Inicijalno je $r$ otklonjeno prirastanjem vokalskoga elementa $e$ u pridjevu erjôv ('loš, zao').

Slogotvorno je $r$ dobilo konsonantsku funkciju u nalazu ùmri gl. pridj. rad. m. jd.

4.1.13. Prijevojni je lik s vokalom $e$ u glagolima rệst i krêst te njihovim izvedenicama (izrệstề - narệsla - narệšte; pokrêla - ukrềla) te u leksemu orệầc sustavno zastupljen u pražničkome govoru. Za značenje 'krađa' dolazi krêja (dicầ su ǐšli u krềju).

4.1.14. Registrirani su primjeri grệb - grêbi $\mathrm{N}$ mn. Značenje 'mjesto gdje se nalaze grobovi, groblje’ pokriva leksem grộbje.

4.1.15. U riječima steplìt, tềpal, teplìca ('toplina') čuva se jedna od praslavenskih dubleta *topl-/*tepl-, dakle ona s vokalom $e$.

11 Nabrojeni su primjeri uobičajeni i u ostalim bračkim čakavskim govorima. Jedino su se u ložiškome govoru u reliktima zadržali primjeri žõja, žõdan i žõjan, gdje je $\bar{o}<\bar{a}$ (usp. Galović 2014b: 88-89). 


\subsection{Konsonantski sustav}

4.2.1. Konsonantski sustav pražničkoga govora čine ovi fonemi:

sonanti

$\begin{array}{llll}v & & & m \\ & l & r & n \\ j & & & n\end{array}$

šumni konsonanti

(opstruenti, šumnici)

$\begin{array}{cccc}p & b & f & \\ t & d & & \\ c & & s & z \\ t^{\prime} & \left(d^{\prime}\right) & & \\ \check{c} & & \check{s} & \check{z} \\ k & g & \chi & \end{array}$

4.2.2. Nazalni se $n$ ostvaruje u svojoj velarnoj varijanti ispred $k$ i $g$ : [čûyka], [tōykâ] neodr. pridj. ž. jd., [štôyga] ('stup, podupirač').

Fonem $c$ ima nešto mekši izgovor, ostvaruje se gotovo kao srednje $\breve{c}$.

4.2.3. Distribucija je konsonanata, također, uglavnom slobodna. Svi se konsonanti mogu nalaziti u inicijalnoj, medijalnoj i finalnoj poziciji u riječi, izuzimajući izvjesna ograničenja u konsonantskim skupinama.

Od finalnih se konsonantskih skupina u domaćim riječima javljaju st, št', zd (za žd nema potvrda): līnôst, môst ('mast'); gödišst' G mn., prĩšt'; zvĩzd G mn. Riječi preuzete iz drugih jezika narušavaju izneseno pravilo: deštûrb ('smetnja'), finônc ('porezno-carinski stražar'), furēšt, jandôrm ('žandar'), kortejônt ('simpatija, udvarač'), mužikônt. Ponekad se te skupine razbijaju umetanjem vokala (v. 4.1.6.).

4.2.4. Fonem $\zeta \check{\zeta}$ nije zasvjedočen $u$ inventaru konsonantskih fonema, što je jedna od temeljnih čakavskih vlastitosti. Prazno je mjesto u kojem se nije razvila fonemska jedinica 亏̌ zaposjeo ž: svjêdožba, žề, žìgerica.

4.2.5. U konsonantskim se sustavima čakavskih govora fonem $x$ vlada kao stabilan. Da je tako i u pražničkome govoru, signaliziraju ovjere: xãjete 2. mn. prez. ('mariti'), xlōdìt, xmūtầ ('pokvareno jaje'), xudobà; doxodî gl. pridj. rad. m. jd., mixũr, mūxộr ('vrsta trave'), nëxotet' ('nehotice'), nesxõran ('nezahvalan'), oxãšstriš 2. jd. prez., straxîv, uzjãxo gl. pridj. rad. m. jd., zaxlōdìt; grĩx, maštìlix G mn., püx ('vrsta životinje'), siromâx, smĩx, sûx, tũjix G mn.

Fonem $x$ može otpasti u izoliranim riječima, kao npr. u dr̈temo 1. mn. prez.

4.2.6. Potvrde dopuštaju zaključak da fonem $f$ uglavnom dolazi u riječima stranoga postanja: faturêta ('posao izvan redovitoga posla'), ferõl, 
fregàt, frementũn, fundàt' ('talog crne kave'), fundamềnat, garîful ('karanfil'), kafện ('smeđ'), naftalîna, profešũr, rêful ('snažan udar vjetra'), Sërafin, šufištik ('sitničav, pedantan'), šufit, trëfit, tüfina ('miris stareži').

Kako se očekuje, fonem $f$ rezultat je izmjene stare skupine $p v$ : üfońe, üfot se.

Skupina $x v$ svela se na $f$ u većinskim primjerima: fōlà (folã ti), fõlimo 1. mn. prez., pofōtīle gl. pridj. rad. ž. mn., zafölìt. Ipak, u riječima Xvõr/Fõr i Xvorãni/Forãni cirkuliraju dvostruke varijante.

Zasebno treba istaknuti nalaze tipa xumät, xumõr gdje je $x$ zauzeo mjesto fonema $f$.

4.2.7. Fonem $j$ refleks je jotacije skupina * $d i$ i $d \partial j$ u premoćnome broju slučajeva: mejõš, mlajarìja, prêja, rôjen, rôjok, sãja, slãji, tujîn, žễja, a isti je ovjeren i u nizu primljenih riječi: jakêta, jelộz ('ljubomoran, zavidan'), jêmetar ('geometar, mjernik'), jêmper, jentîl ('elegantan, vitak'), kortejônt, štajũn, vijôj. Efemerno se javljaju primjeri s fonemom d', kojega treba smatrati kao noviji import: dîta, lidệr ('vodenast'), obrõd'en, ônd’el ('anđeo').

4.2.8. Protojezične su konsonantske skupine ${ }^{*} z g i \mathrm{i}{ }^{*} z d i$ te starojezične zgəj i zdaj dale čakavske rezultate: dažjà G jd., grộzje, gvôzja ('oveća stupica od željeza'), gvozjīcà ('stupica od željeza'), möžjoni, zvî̌jot - zvižješ 2. jd. prez. Harmoniju remeti izolirani leksem gvožd’arïja.

4.2.9. Fonem $t^{\prime}$, koji ima tipičan čakavski izgovor, ${ }^{12}$ odraz je jotacije $u$ skupinama *ti i təj. Za ilustraciju može poslužiti nekoliko primjera: brãta, küta, kusìt', nột, prũte, srìta.

4.2.10. Śćakavski je refleks št’ iz primarne jotacije skupina *skin, *sti te iz sekundarne jotacije skupina skəj, stəj dosljedan u pražničkome govoru:

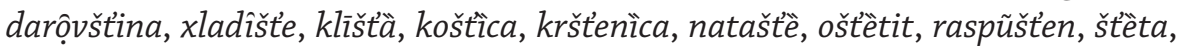
štốp, štù̀ cot - štùco 3. jd. prez., ušteẹdìt, uštīpô gl. pridj. rad. m. jd.

4.2.11. Brački teren nije jedinstven ni po čuvanju skupine čr. Stara je skupina čr u govoru Pražnica zadržana u priličnoj mjeri: črîvo, črjenïca, čřv, črvẹj ('vrsta jestive trave'), učr̀pot, ali crjệnäk ('vrsta grožđa; vrsta vinove loze'), crńãvina ('crni gusti oblaci'), pocrvenìt.

4.2.12. Stara je konsonantska skupina čt, kako se očekuje, prešla u št: poštện, poštīuăt, proštìt - proštîj 2. jd. imp!, štẹ̃ne ('čitanje u crkvi').

12 O artikulaciji t’ v. Moguš (1977: 65). 
4.2.13. Konsonantske su skupine šk, šp, št razvijene u primljenih riječi: škandalèt, škartôc, škîna; špalîna, špańulèt, šporküja; poteštôt, šotovêšta, štüf, štümak. U manjem su broju leksema spomenute skupine ovjerene kao nepalatalne, npr. manìstra, sküla, spîza.

4.2.14. Na granicama prefiksalnoga i korijenskoga morfema u prezentskim se osnovama glagola prefigiranih $s{ }^{*} i t i$ konsekventno ostvaruje skupina jd: dộjden, izōjdìte, nõjdete, prộjde, obõjdemo.

$\mathrm{U}$ infinitivnim je osnovama ovjeren $t^{\prime}$, što je rezultanta procesa $j t>t j>$ $t^{\prime}:$ dột', nột t', pột i sl.

4.2.15. U govoru je Pražnica na mjestu fonema ĺ nastupio j: grmjãvina, grübji komp., divjõk, kãpja, košùja, krõj, kudîja, kũpjen pridj. trp. m. jd., medãja, nedîja, nevôja, pogôbjen, pồsteja, slômjen pridj. trp. m. jd., šūpjà neodr. pridj. ž. jd., võjon se 1 . jd. prez., zemjä, žũj. Zbog promjene $l$ u $j$ ne može se zaključiti je li epentetski $l$ bio umetnut u sljedove $p j, b j, v j, m j$.

Veoma su usamljeni primjeri u kojima na mjestu ĺ stoji l: plèskot, Žệlko (Žẹlkota GAjd.).

U pojedinim riječima jotovanje nije provedeno, odnosno izgovor je jedinica l i j nesliven: Böljanin, soljệra, vesệlje.

4.2.16. Mijena je finalnoga $-m$ u $-n$ u nastavcima i nepromjenjivim riječima svojstvena i ovomu govoru: čùjen, mojộn sestrộn, pĩton 1. jd. prez., sa tẹ̃škin životộn, sêdan, s kĩn.

$\mathrm{Na}$ dočetku leksičkoga morfema promjenjivih vrsta riječi - $m$, u pravilu, nije podvrgnut promjeni: brãtim, dîm, kûm, mulôm ('rebra s mesom'), srôm, zōjôm. Pomalo je neobično, no ipak se razmjerno rijetko može javiti i - $n$, primjerice ûltin.

Zamjena je - $m$ s - $n$ zavladala i na dočetku unutrašnjega sloga: Xunčônka ('stanovnica Gornjega Humca'), osandesẹ̃t, zapôntit.

U položaju se ispred bilabijala $b$ i $p$ ostvaruje $[m]$ : imbotîda ('vrsta prekrivača'), imbôzd, kampanẹl, tệmpal ('crkva').

4.2.17. Finalni je slogovni $l$ :

a) zadržan na dočetku riječi u imenica, pridjeva i priloga: čãvol, jãval, kotôl, macệl ('klaonica'), mîsal, pandîl ('suknja'), posôl, stộl; dêbel, ôbal, stãbil ('čvrst, stabilan'), zdrîl, zôl; odizdôl/ozdõl, pộl;

b) zadržan na dočetku unutarnjega sloga: barîlci $\mathrm{N}$ mn. (prema barīlac), golcà G jd. (prema goläc), molbà, mũlci $\mathrm{N} \mathrm{mn}$. (prema mūlàc), põlcix G mn. 
(prema pōlâc 'vrsta nametnika na boru'), učẹlka G jd. (prema učêlak 'zabat, pročelje kuće'), veltrîna;

c) utrnut u jednini muškoga roda glagolskoga pridjeva radnoga: dočêko, doxodî, dôni, dōvô, metồ, mlōtî, povũko, vãze, zapô.

4.2.18. Rasterećenje napetosti u rubnim zonama sloga funkcionira na ove načine:

a) afrikata se zamjenjuje frikativom: böraški, küška, kvôška, mãška, prôžniški, težõški;

b) okluziv se zamjenjuje sonantom: ölbor, olgojīla gl. pridj. rad. ž. jd., polpīsàt, ženîlba te u primjerima tipa ol mène, pol krộv;

c) okluziv se likvidira: splìski, susîstvo.

Prisutna je tendencija za uklanjanjem netipičnih konsonantskih skupina na način da se prvi član skupine likvidira: čelà, tệr, dì, kộ, sovàt, šenìca, tìca.

4.2.19. Sonant $v$ u okruženju sa sonantom $r$ ili slogotvornim $r \mathrm{u}$ istome ili u sljedećem slogu pokatkada može biti eliminiran: sēkar, sekřva, srbĩ 3. jd. prez., ali četvriti, mrtvăc, stvorìt, svr̈dol ('svrdlo'), tvr̆d.

4.2.20. Skupina je vs (< vas < *vbs) nakon redukcije poluglasa i provedene metateze izmijenjena u sv: svâk, svê, svêmu. U liku vâs, koji je frekventan u govoru, metateza nije provedena jer je 'šva' u jakome položaju dao $a$, pa nije prijetio razvoj netipične konsonantske skupine.

4.2.21. Supstitucija je intervokalnoga ž s $r$ u prezentskoj osnovi glagola 'moći' (< ${ }^{*}$ mogti) evidentirana u materijalu: mồreš, möremo. Pored ovih se oblika sreću i oblici möžeš, möžemo, ali žive i likovi tipa mögeš.

4.2.22. Da je u nekim slučajevima došlo do kontaktne i distantne asimilacije, pokazuju dostupni nalazi: š ńïma, š noọn; ošūsìt, šašit - šašilla gl. pridj. rad. ž. jd., šũša.

Disimilacijske su pojave očigledne u nekim riječima: zlãmenot se zlãmenoj se - zlãmenola se, sūmjät - sũmjon 1. jd. prez., sumjîv, a zanimljivo je istaći i leksem gũbno ('guvno'). Prema $r$ dolazi $l$ u primjeru lebrồ te u primljenica poput legrût, šaltûr.

4.2.23. Palatalni je nazal ń u pokojoj riječi izgubio palatalnost: ditînstvo, jônce A mn. (prema jãñac).

4.2.24. Govoru nisu strana ni umekšavanja nazala u ponekom primjeru: gńīzdò, gńộj, gńùsa. 
4.2.25. Od ostalih posebnosti valja izdvojiti sljedeće:

Stara je konsonantska skupina $z r$ u pretežitome broju ovjera razbijena dentalom d: sazdrïlo gl. pridj. rad. s. jd., zdrîl.

Unutar sastava stare konsonantske skupine žr može biti umetnuto $d$ : nãždrla, nãždri, ali žerät - žêredu.

Stara je skupina st u riječi caklö metatezom dala c.

Predmetanjem je $s$ stvorena sekundarna skupina $s p$ u imenici spũž.

Čuva se stara skupina sl u primjeru slìva.

Metateza je nastupila u leksemima grãvon ('gavran'), mañìga i zĩkva ('zipka').

\subsection{Akcenatski sustav}

4.3.1. Inventar prozodijskih jedinica obuhvaća tri akcenta: kratki

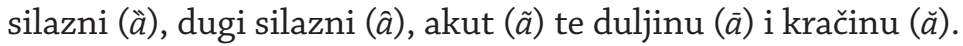

4.3.2. Akcent $\hat{a}$ je dug i silazan, akcent $\tilde{a}$ je skokovit i zavinut, akcent $\ddot{a}$ je kratak i silazan, no kadšto se može dobiti dojam da je ponešto tromiji. Duljine su ispred akcenata veoma izrazite „s tendencijom prema uzlaznosti” (Šimunović 2009: 31).

4.3.3. Distribucija je akcenata uglavnom slobodna, odnosno svaki od pojedinih akcenata može stajati u inicijalnoj, medijalnoj i finalnoj poziciji u riječi.

Kratki se silazni akcent javlja:

- u jednosložnim riječima: rêt', vâš, trìn

- u inicijalnome slogu dvosložnih riječi: müka, plöča, srìtan

- u inicijalnome slogu višesložnih riječi: glëdomo, kökoše A mn., mêjedu 3. mn. prez.

- u medijalnome slogu višesložnih riječi: dvojīca, potrība, zamëtemo 1 . mn. prez.

- u finalnome slogu dvosložnih riječi: kopàt, ništồ, rosă

- u finalnome slogu višesložnih riječi: dužinì DL jd., vretenô, vučedü 3. jd. prez.

Dugi se silazni akcent javlja:

- u jednosložnim riječima: mlôd, rîč, sộl

- u inicijalnome slogu dvosložnih riječi: bûža, mệtar, svộjta 
- u inicijalnome slogu višesložnih riječi: dvôdese(t), nộnotu DL jd., nôpoko

- u medijalnome slogu višesložnih riječi: tikulôtix $\mathrm{G}$ mn., karatîlcima(n) DLI mn., šaltộra

- u finalnome slogu dvosložnih riječi: caklộn I jd., kršjệ, ostô gl. pridj. rad. m. jd.

- u finalnome slogu višesložnih riječi: izbodện gl. pridj. trp. m. jd., pantagôn, udovîc $\mathrm{G} \mathrm{mn}$.

Akut se javlja:

- u jednosložnim riječima: pọ̃č, pũk, smrĩč

- u inicijalnome slogu dvosložnih riječi: jãstreb, tãmo, žũjix G mn.

- u inicijalnome slogu višesložnih riječi: crĩkvica, nẹtemo, pãmeti $\mathrm{G}$ jd.

- u medijalnome slogu višesložnih riječi: kopãna, krepãla gl. pridj. rad. ž. jd., razgovõrojte 2. mn. imp!

- u finalnome slogu dvosložnih riječi: blejũ 3. mn. prez., febrõr, gorẹ G jd.

- u finalnome slogu višesložnih riječi: kantadũr, prikučẹrr, xudobẽ G jd.

Distribucijsko se ograničenje odnosi na vokal a pod kratkim silaznim akcentom koji ne može, u načelu, stajati u inicijalnome ili medijalnome slogu. Isti se u navedenim pozicijama dulji i stoji pod akutom: lãstavica, mlãdost, poznãjen 1. jd. prez., tugovãla gl. pridj. rad. ž. jd. Riječ je o mladome duljenju koje se odvilo u posljednjih dvjestotinjak godina. Takav je tip duljenja gotovo dosljedan jer zahvaća svako nefinalno à (osim u futurskim oblicima tipa zvätete i sveza tipa sesträ je), ima i nekih izoliranih primjera (pretežito posuđenice ili novije riječi) u kojima nije provedeno, npr. banäna, fâjerica ('upaljač'), kầpa (uz često berìta), kầštika, sầstanak, pàzit - pàzin, ali vãdit - vãdin i sl. (usp. Kapović 2015: 613).

Duljine su nakon akcenta utrnute, čuvaju se jedino predakcenatske. U jednoj riječi može stajati jedna duljina. Sudeći prema prikupljenoj terenskoj građi, duljine se mogu javiti jedino ispred silaznih akcenata: ${ }^{13}$

13 U pjesničkoj zbirci Tomislava Dorotića U pustinji jubavi Petar Šimunović na ovaj način akcentira pojedine primjere: stīnẽ $(25)$, snōgẽ $(26,37)$ i sl. Za ovoga istraživanja nestabilni slijed prednaglasne duljine i akuta, koji je ustvari sekundaran jer je oblik tipa dušẽ s kračinom primaran, nije potvrđen. Konzultanti sljedeće primjere izgovaraju na ovaj način: brodê, dušẽe, kumẹ, rukẹ, stronẹ, trovẹ, zimẹ. 
- pred kratkim silaznim: nōrôdu DL jd., ugrīzê 3. jd. prez., vinnà G jd. mūtẹžz.

- pred dugim silaznim: frementūnộn I jd., mlōtî gl. pridj. rad. m. jd.,

4.3.4. Enklitike često nisu pod akcentom: jõ t’u vộ proštìt; onà bi svè znãla, no u stanovitim okolnostima preuzimaju akcent: čãvol če sê küje końê; jemô je sväk dôma če tề ìst; ne bìsmo dộ̃̌li krãju.

4.3.5. Neoslabljeno je pomicanje akcenta, tj. preskakanje akcenta ${ }^{14}$ na proklitiku, evidentirano u nekim primjerima:

- preskakanje na prijedloge: krồz nos, pôl ruku, ù oko, ù kosti, ù more

- preskakanje na veznike: pedesệt ì pet, trist ì šest

- preskakanje na negaciju 'ne' u usamljenim primjerima: në znon, nềva/nề vaja.

Frekventna su pomicanja akcenta na prijedlog uz duljenje prijedložnoga sloga: nã ruke, nã glovu.

Kod nekih se zamjeničkih oblika na prijedlogu javlja akut: zõ se, nõ te, ũ me.

4.3.6. Valja opaziti oblike tipa gũbno, pĩsmo, dakle s ujednačenim akutom na osnovi (usp. Kapović 2015: 421-424).

4.3.7. U genitivu i dativu osobne zamjenice 'ja' dolazi očekivani akcent mène, mèni.

4.3.8. Zanimljivo je istaknuti nalaze poput grîzla, lẹgla, lîzla, mûzla u kojima dolazi duljina, kako je to u pojedinim bračkim idiomima, iako se tu očekuje kračina jer ondje nije bilo poluglasa.

4.3.9. U govoru se provodi predsonantsko duljenje koje je dalo dugi silazni akcent. Potvrdom su primjeri: dîm, gospodîn, kộn, kotôl, mrtôv, posôl, rôj.

4.3.10. Osim predsonantskoga duljenja u govoru je na snazi i duljenje ispred zvučnih konsonanata koje također rezultira dugim silaznim akcentom: bộb, grộzje, kộzii, obîd, obrôz, prôg.

14 Preskakanje rezultira kratkim silaznim akcentom na inicijalnome slogu fonetske riječi za razliku od prenošenja koje rezultira kratkim uzlaznim akcentom na slogu pred onim slogom s kojega je akcent nestao. Hoće li u pojedinome govoru doći do preskakanja ili prenošenja ovisi o povijesnim razlozima (uz iznimke), ali i o samome idiomu i primjeru (Kapović 2015: 32). 


\section{Zaključak}

Mjesni govor Pražnica na otoku Braču do sada ni je opisan ni na jednoj jezičnoj ravni. U članku su analizirane fonološke posebnosti pražničkoga govora dobivene za novijega terenskoga istraživanja. Rezultati su pokazali očekivane značajke koje su svojstvene i većemu broju bračkih čakavskih govora (vokal $a$, odnosno $o$ kao rezultat poluglasa; pokoji primjer čakavske jake vokalnosti; ikavski refleks jata uz poneki ustaljeni ekavizam; vokal $u$ kao odraz stražnjega nazala i slogotvornoga $l$; dvojaka zamjena prednjega nazala; primjeri tipa rệst, krêst, orệbàc te grệb; nepostojanje fonema ऊ̌; čvrsta pozicija fonema $x$ if; fonem $j$ kao dominantan refleks primarne i sekundarne jotacije dentala $d$; šćakavizam; postojanje tipičnoga čakavskoga $t^{\prime}$; uglavnom čuvanje skupine čr; primjeri tipa dọjden; promjena $l \mathrm{u} j$ te promjena finalnoga $-m \mathrm{u}-n$ u nastavcima i nepromjenjivim riječima; gotovo sustavno rasterećenje napetosti u rubnim zonama sloga; zadržavanje finalnoga slogovnoga $l$ osim u jednini muškoga roda glagolskoga pridjeva radnoga i sl.; prijelaz dugog a u o te duljenje kratkog a u nefinalnome slogu u $\tilde{a}$; troakcenatski sustav s duljinama ispred akcenta). Pojedine promjene i inovacije koje se sreću u novije vrijeme u brojnim čakavskim govorima, a tako i u onima otoka Brača, nisu za ovoga istraživanja ovjerene u mjesnome govoru Pražnica. Pokazuje se, dakle, da je pražnički idiom čvrst i dobro sačuvan, a da su mogući nanosi sasvim ograničena domašaja.

\section{OGLED GOVORA}

Govori Franka Jerčić (1926.)

Jõ san bĩla ostãla sa mãteron i jôš jednộn sestrộn jer mi je otâc îšo u Amêrike i nĩ jemô ol čêga živìtt, i da tee ộn čagộl stêté i vrōtìt se dôma. Ali je sudbinä bĩla tãka da ộn nĩ nīkal stêko, nego ùvik je bî sirotâ... Pôsli je dộšlo vrîme da bi ộn mêne dìgo tãmo. A sestrầ se počệla odōvàt, onà je mlãjo ol mêne, ali êto, trêfilo non je lîpo. I ondầ se počệla odōvàt. I ondâ jõ jãdna ča tûu? Ộn da te mi poslà(t) kôrte, a jõ về' vāmồ se zajubĩjen. I nề sômo u jednẹga, nego u dvô, trî. I ondà ča tüu(n), kül t’u(n)? Ondà... kakồ t’u mãter ostãvi(t)? Da nekà grẽ i onà. Jõ govôrin: pộte ti rộg. I ondà je ộn mêni tãko priko nikêga konzulātâ naprãvi kôrte da jõ môgu dột u Santijâgo. I ondà jõ se về(t) počẹla prîlî̌no zaglêdot za sadãšńega mûža i jõ odustãla. I ondâ se bî mãlo sjīdî. A govorìli su da neka jõ dộjden tāmô da su 
nikêga bogatūnà iz nãšega selà, da je bogàt, a da nĩ ožênen. (...) I ondầ nīsôn ǐšla, èto, $i$ ondâ san se odôla za ovẹga siromãxa - nĩ jemô bäš ni kütu ni küčište, nìti san znãla dì te mi bït pôsteja ni nīšta nīsôn znãla. I tãko je ostãlo... i tãko žìuìla do danàs... Jer nīsôn nïkal bĩla glõdna. Mûž mi je rōdî svãki zanõt, a nôjvête marangunïju. I ondà smo tãko živîli, i èto do danäs jõ jêmon devedesệt i jednü ìpo gôdinu. Ovề zôdńe dône ništồ san se razbolìla, a ìnače do täl san üvik xodîla sa katrîdon na kôla, isküxola obîd mêni, mûžu... jednà mi je tệr u Nềmašku, a jednà tãmo... i nề znon ča tề bìt od mêne... fola Bögu, ù ruke Böžje.

Govore Marija Kusanović (rođ. Klinčić) (1930.) i Slobodan Kusanović (1957.)

- ...črvễj... tộ Van je trōvà če smö jīli i brôli.

- Ka san xodî u Pucî̌šta u skülu, po ondâ dọ̃j dôma, ondầ vazẹst kozù u pãšu i ondà črvẹjaà $i$ koromãča $i$ kộzje brodẹ... nĩ bîlo ondà banänix ni tikulôtix!

- Jõ san se odõla pedesệt i trêté... ondâ je bîlo pôsli rãta... nĩ se imãlo nïšta... U Pučšsta ìša bi u skülu ộn i drügi brät po bi nin bĩla pofrìgola jôje i stãvila u dvî fêtice krüxa če sần dồma ispềkla.

- Da nĩ ondà bîlo kozẹ̃i da nĩ bîlo mlìkà, svì bi bîli krepãli òl gloda!

- Jẹ znôš če jề žejûd? Ë, mĩ smo ga pēkli, bî je gôrak... A kal smo pôčeli fumàt, ondâ kadûje i cmìja zamotât u blök od autộbusa. Ondâ u tî blök od autộbusa če tî je potrōšen smotät kadüje i cmìja... ìxxx... tồ je dìmilo kồ âuta.

\section{Literatura}

Derksen, Rick (2008) Etymological Dictionary of the Slavic Inherited Lexicon, Brill, Leiden - Boston.

Finka, Božidar (1971) „Čakavsko narječje”, Čakavska rič 1/1-2, 11-71.

Fonološki opisi (1981) Fonološki opisi srpskohrvatskih/hrvatskosrpskih, slovenačkih i makedonskih govora obuhvaćenih Opšteslovenskim lingvističkim atlasom, ur. Pavle Ivić, Posebna izdanja ANUBiH, LV/0, Odjeljenje društvenih nauka, Sarajevo. 
Galović, Filip (2013) „Jezične osobitosti mjesnoga govora Ložišća na otoku Braču", Fluminensia, 25/1, 181-198.

Galović, Filip (2014a) „Govor Donjega Humca”, Jezikoslovlje, 15/2-3, 231267.

Galović, Filip (2014b) „Nazivi za zanimanja, zvanja i počasne službe romanskoga podrijetla u govoru Ložišća na otoku Braču”, Čakavska rič, 42/1-2, 87-112.

Galović, Filip (2016) „Stjepan Pulišelić i “Glos sa škrop”, Čakavska rič, 44/12, 141-176.

Hraste, Mate (1940) „Čakavski dijalekat ostrva Brača”, Srpski dijalektološki zbornik, 10, 3-66.

Kapović, Mate (2015) Povijest hrvatske akcentuacije. Fonetika, Matica hrvatska, Zagreb.

Langston, Keith (2006) Cakavian prosody: the accentual patterns of the čakavian dialects of Croatian, Slavica Publishers, Bloomington.

Lisac, Josip (2009) Hrvatska dijalektologija 2: Čakavsko narječje, Golden marketing - Tehnička knjiga, Zagreb.

Lisac, Josip (2017) „Pražnički govor u poeziji Tomislava Dorotića”, Život mora biti djelo duha. Zbornik posvećen prof. dr. sc. Dubravki Sesar, ur. Zrinka Kovačević i Ivana Vidović Bolt, Disput, Zagreb.

Lukežić, Iva (2012) Zajednička povijest hrvatskih narječja: 1. Fonologija, Hrvatska sveučilišna naklada - Filozofski fakultet u Rijeci - Katedra Čakavskog sabora Grobnišćine, Zagreb - Rijeka - Čavle.

Moguš, Milan (1977) Čakavsko narječje. Fonologija, Školska knjiga, Zagreb.

Sujoldžić, Anita; Finka, Božidar; Šimunović, Petar; Rudan, Pavao (1988) „Sličnosti i razlike u govorima otoka Brača kao odraz migracijskih kretanja", Rasprave Zavoda za jezik, 14, 163-184.

Šimunović, Petar (2005) Toponimija hrvatskoga jadranskog prostora, Golden marketing - Tehnička knjiga, Zagreb.

Šimunović, Petar (2009) Rječnik bračkih čakavskih govora (2. izd.), Golden marketing - Tehnička knjiga, Zagreb. 


\section{SUMMARY}

Filip Galović

\section{THE PHONOLOGICAL SYSTEM OF THE LOCAL DIALECT OF PRAŽNICA}

Although the majority of features of the local dialect of the village of Pražnica can be found in the synthetic descriptions of the Brač Čakavian local dialects, this local dialect has not been fully described on any linguistic level, and only partial information about it is available. In this paper, on the basis of his recent field investigations, the author describes the phonological features of the Pražnica local dialect.

The results revealed the existence of expected characteristics which are present in the majority of Čakavian dialects on the island of Brač: the semivowel produces the vowel $a$, that is, $o$; we find some examples of Čakavian vocalization of vowels in weak positions; Ikavian reflex of ${ }^{*} \check{e}$ with a few Ekavian forms; the syllabic $l$ and OCS ${ }^{*} q$ are consistently changed into the vowel $u$; the reflex of $\mathrm{OCS}^{*} \varepsilon>a$ after palatal consonants and ${ }^{*} e$ > $e$ after other consonants; examples like rệst, krêst, orệầc and grệ; no

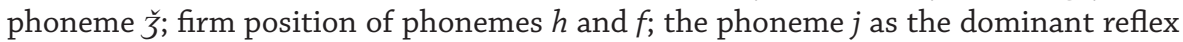
of primary and secondary jotation of the dental $d$; "šćakavism", that is, the sequences *st' and ' $z d$ ', as well as *sk, 'zg that give šć, zj/žj; the existence of typical Čakavian $t$ '; the ${ }^{*} \check{c} r$ sequence is preserved in most cases; examples such as dọjden; the change of $\hat{l}$ into $j$; change of $-m>-n$ in final position in grammatical endings and indeclinable words; almost systematic modification of consonant clusters; the consonant $l$ is preserved in the syllable-final position but not in the singular of masculine nouns in past participle; the change of long $a$ into $o$ and the lengthening of short $a$ into $\tilde{a}$ in nonfinal syllables; a three accent system with a length before the accent.

The analysis shows that the local dialect of Pražnica is a stable system which has preserved its structure and that the more recent changes and innovations that are found in some other Brač local dialects have not penetrated this local dialect.

Keywords: Čakavian dialect; south Čakavian dialect; Brač local dialects; local dialect of Pražnica; phonology 